\title{
Chord language and theory of everything
}

\author{
Li xiaohong \\ Lini(Corresponding author)
}

\begin{abstract}
Is there a unified natural principle or theory of all things behind the natural phenomena that are observed in different disciplines and scattered? If there is such a thing, it should have a wide universality, and the chord language phenomenon seems to have this feature.
\end{abstract}

Chord languages have distinct physical and mathematical forms: discrete spectrum, chords (open, closed, non-linear string), symmetrical, mirrored, etc. In music, painting, meridian (Chinese ancient medical theory) and other disciplines, the generation of time, space, life, spiritual and other semantic expressions, beyond the universality of the discipline, easy to observe, verify, Like the theory of all things.

The following is the chord value formula used in music and painting. Is this a quantum formula? $\mathrm{S}=\mathrm{HV},(\mathrm{S}=$ semitone, $\mathrm{H}=$ equal temperament constant, $\mathrm{V}=$ frequency), minimum discrete value. $\mathrm{I}=\mathrm{H}^{\wedge} \mathrm{n} \cdot \mathrm{V}$ (I=sound, $\mathrm{n}=$ sound value), allowing discrete values; $C=H^{\wedge} n 1, n 2, n 3, n^{*} . V(C=$ chord $)$, discrete value spectrum.

Music and painting are chord language phenomena, with discrete spectral forms unique to chord language: chords, tones, scales, etc., respectively: time and space, mathematically mutual: reversemirror relationship.

Chord language is not only a spiritual phenomenon (music, painting), but also a physical phenomenon (discrete spectrum, string), observing chord language events, such as: music, painting, etc. - also observing physical events, it has spiritual-natural isomorphism, This is its philosophical significance: there is a certain natural principle and law between spirit and nature.

The chord language is an ancient knowledge system whose mathematical model dates back to Pythagorean temperament in ancient Greece. After the gradual improvement of musicians of the dynasties, the ancient Chinese medical theory - Meridian observation of positive-negative (yin-yang) rules - this is an important attribute of chord language, and spatial (geometric) semantics can be observed in chord paintings: Strings (open, closed, non-line string), these observations complete the recognition of the chord languageknowledge.

Key words: chord language, chord space-time, chord life, theory of everything, music, painting, meridian, string theory 


\section{Two languages and a world view}

Humans have two sets of language systems: naming symbolic language and chord language. The former is the artificial symbolic language, the latter is the physical language, with certain physical and mathematical forms, involving two different logics, spiritual principles, and even two worldviews. Many differences in human understanding are related to this.

The two language systems produce two layers of language (logic, spirit): symbolic language (artificial language) and chord language (physical language), understanding the two language layers and the principle of action, interrelations, compilation process, is the need of human understanding of themselves, spirit and nature.

In symbolic languages, named symbols and named objects produce a difference between spiritual and natural, subjective and objective.

In chord language, spirit (music, painting, etc.), life (meridian) appear as physical form (discrete spectrum, string), with spiritual-natural isomorphism and homomorphism.

The above expression is just plain common sense - discrete spectrum (energy) is also a common mental form, e.g., music.This may lead to philosophical questions: spirit and nature, mind and matter, objectivity, etc.

Another important area of chord language is meridian (the theory of ancient Chinese medicine), which is a chord coding system of life, with discrete spectral forms (chords, tones, scales, etc.), which exert control over the process and purpose of life. One of the most important attributes is: Yin-yang (positive-negative), which determines the grammatical-semantic-symmetry rules of chord language, which is different from the life science view, indicating that there are more secrets in the phenomenon of life.

Most disciplines (science, philosophy, literature, etc.) use named symbolic language, and a few disciplines, such as music, painting, using chord language (physical language), this distinction is very important, it shows: music, painting physics (discrete spectrum, string), mathematical (geometric) properties, spiritual and physical homogeneity, It is also the basis of observation and understanding of chord time and space.

\section{Two views of time and space}

Humans have two sets of space-time expressions: reference system space-time and chord timespace, simply put: reference system space-time from the clock, ruler and other external reference system, chord space-time from the discrete spectrum, string (opening string, closed string, non- 
line string), usually, science, physics using the reference system of space-time, music, painting using chord space-time.

Chord space-time is the semantic expression of chord language, music is the expression of time, and painting is the expression of space. Both of them have discrete spectrum forms: chord, mode, scale, etc. Mathematically, they are inverse mirror images of each other, and can be converted to each other through chord value formula.

In chord painting (chord geometry), specific chords have specific spatial-geometric semantics: open chords (minor chord), closed strings (major chord), non-line strings (Discord), which produce all spatial states and spatial interactions, which are fundamental features of chord space (geometry) and are easy to observe and validate in chord painting This should be good news for string-M theory.

Again: science, physics, the use of reference system space-time, music, painting, etc. use chord space-time, the following are added:

Reference system space-time: From the external reference system: ruler, clock, assigned background reference system, etc. to generate position, shape, motion description, space-time is a measure from the external reference system.

Chord space-time: is the form of energy, information: the quantum chord spectrum, strings (opening, closing, N-strings), and thus produce space-time state, interaction and motion, without relying on the clock, ruler and other external measurement reference system. According to the above characteristics, chord space-time can also seem to be called: quantum-string space-time.

Reference frame space-time will block chord space-time (quantum space-time), for example:

Using clock, ruler and other external measurement reference system to measure chord space-time system;For example, the works of Beethoven, Mozart, van gogh and monet can establish a theoretical model of space-time from the measured values, but there is no chord spectrum and its energy and information functions in the space-time model based on the external reference system.

Space-time expression is the intersection of physics and music-painting, and it is also the common center, but they are different ways of expression of time and space, and even different view of space-time. In particular: chord space-time has a distinct physical form: discrete spectrum, string (open, closed, non-line string), this should be quantum theory, string theory characteristics, but also the question that this paper must ask.

\section{Other}

Chord language is a common human blind spot for two reasons: 
1. Differences between the principles and methods of the two languages: The chord language usually occurs in the background and bottom layer of the symbol language, and does not depend on the symbolic language system. It is not easy to be noticed by the symbolic language and rationality.

2, the basis of chord language observation is: music, painting, meridian and other chord language phenomenon, due to education reasons, many people are not familiar with this field.

新增知识点: 和弦语言, 和弦时空, 和弦绘画, 和弦数学, 和弦生命。

涉及已有知识点: 音乐理论, 音乐数学, 色彩理论、物理, 生命, 经络学, 万物理论。 Added knowledge points: chord language, chord time and space, chord painting, chord math, chord life.

Involved in existing knowledge points: music theory, music mathematics, color theory, physics, life, meridian, all things theory.

\section{Reference}

1. Chord space-time, Li xiaohong,24th World Congress of Philosophy Beijing 13-20 August 2018

2. Spiritual chords, Li xiaohong,24th World Congress of Philosophy Beijing 13-20 August 2018

3. Chord language-Equal temperament logic and Equal temperament painting,Li xiaohong,ISBN:9781370273348

4. Chord language - chord painting atlas, Li xiaohong,ISBN: 9781370273348

5. Greene,Brian.The Elegant Universe, W.W.Norton and Co.New York,NY.c1999 ISBN 0-37570811-1.

6. 加来道雄. 《超越时空》. 上海世纪出版集团. 2009. ISBN 978-7-5428-4804-8.

7. Davis Henry. The Republic The Statesman of Plato: London: M. W. Dunne ， 2010: ISBN 978-1-146-97972-6

8. Dahlhaus, Carl. Gjerdingen, Robert O. trans. (1990). Studies in the Origin of Harmonic Tonality, p. 141. Princeton University Press. ISBN 0-691-09135-8.

9. van der Merwe, Peter (1989). Origins of the Popular Style: The Antecedents of TwentiethCentury Popular Music. Oxford: Clarendon Press. ISBN 0-19-316121-4.

10. Nettles, Barrie \& Graf, Richard (1997). The Chord Scale Theory and Jazz Harmony. Advance Music, ISBN 3-89221-056-X

11. M. Planck, A Survey of Physical Theory, transl. by R. Jones and D.H. Williams, Methuen \& Co., Ltd., London 1925(Dover editions 1960 and 1993)including the Nobel lecture.

12. J. Mehra and H. Rechenberg, The Historical Development of Quantum Theory, Vol.1, Part 1, Springer-Verlag New York Inc., New York 1982.

13. Lucretius, "On the Nature of the Universe", transl. from the Latin by R.E. Latham, Penguin Books Ltd., Harmondsworth 1951. There are, of course, many translations, and the translation's title varies. Some put emphasis on how things work, others on what things are found in nature.

Next page: Chinese version 


\title{
和弦语言与万物理论
}

\author{
李晓虹 \\ 李霓 (通讯作者)
}

摘要: 由不同学科、分散观察到的自然现象后面, 是否存在统一的自然原理或万物理论? 如果存在这种东西, 应该具有广泛的普遍性, 和弦语言现象似有这一特征。

和弦语言具有鲜明的物理、数学形式: 离散频谱, 弦 (开弦、闭弦、非线弦), 对称, 镜像等。在音乐, 绘画, 经络学 (中国古代医学理论) 等学科中产生时间、空间、生命、精 神等语义表达, 具有超出学科的普遍性, 易观察、验证, 似万物理论特征。

下面是音乐、绘画中使用的和弦取值公式, 这是量子公式吗?

$\mathrm{S}=\mathrm{HV}$, ( $\mathrm{S}=$ 半音程, $\mathrm{H}=$ 平均律常数, $\mathrm{V}=$ 频率), 最小离散值。

$\mathrm{I}=\mathrm{H}^{\wedge} \mathrm{n} . \mathrm{V}$ ( I=音程, $\mathrm{n}=$ 音程值), 允许离散值;

$\mathrm{C}=\mathrm{H}^{\wedge} \mathrm{n} 1, \mathrm{n} 2, \mathrm{n} 3, \mathrm{n}^{*} . \mathrm{V}$ ( C $=$ 和弦), 离散值频谱。

音乐、绘画都是和弦语言现象, 具有和弦语言特有的离散频谱形式: 和弦, 调式, 音阶 等, 分别表达: 时间与空间, 数学上互为: 反序-镜像关系。

和弦语言既是精神现象 (音乐, 绘画), 又是物理现象 (离散频谱, 弦), 观察和弦语言 事件, 如: 音乐、绘画等一一也是在观察物理事件, 它具有精神-自然同构性, 这是它的哲学 意义: 精神与自然之间存在某种统一的自然原理、法则?

和弦语言是一个古老的知识系统, 其数学模型可追溯到古希腊时期的毕达哥拉斯律。经 过历代音乐家们逐渐完善, 中国古代医学理论——经络学观察到正-负 (阴-阳) 规则——这 是和弦语言的重要属性, 和弦绘画作品中能观察到空间 (几何) 语义: 弦 (开弦, 闭弦, 非 线弦), 这些观察共同完成了对和弦语言的认识。

关键词: 和弦语言, 和弦时空, 和弦生命, 万物理论, 音乐, 绘画, 经络, 弦理论

\section{两种语言与世界观}

人类有两套语言系统: 命名符号语言与和弦语言, 前者是人工符号语言, 后者是物理语 言, 有着确定的物理、数学形式, 涉及两种不同的逻辑, 精神原理, 甚至是两种世界观, 人 类的许多认识分歧和这个相关。

两种语言系统产生了语言 (逻辑、精神) 的二层结构: 符号语言 (人工语言) 与和弦语 言 (物理语言), 理解两个语言层及作用原理, 相互关系, 编译过程, 是人类理解自己、精 神与自然的需要。

在符号语言中, 命名符号与命名对象产生了精神与自然、主观与客观的差异。

在和弦语言中, 精神 (音乐, 绘画等), 生命 (经络学) 表现为物理形式 (离散频谱, 弦), 具有精神-自然的同构性, 同形性。 
以上表达只是一个显而易见的常识——离散频谱（能量）也是常见的精神形式, 如: 音 乐。这可能带来哲学层面的问题: 精神与自然, 心与物, 客观性等。

和弦语言的另一重要领域是: 经络学 (中国古代医学理论), 它是生命的和弦编码系统, 具有离散频谱形式 (和弦, 调式, 音阶等), 对生命过程、目的发生着控制作用。其中最重 要的属性是：阴-阳（正-负), 它决定和弦语言的语法-语义-对称性规则, 这是不同于生命科 学的生命观, 表明生命现象中还存在更多地秘密。

大多数学科 (科学、哲学, 文学等) 使用命名符号语言, 少数学科, 如: 音乐、绘画使 用和弦语言 (物理语言), 这是一个重要路径: 它显示出: 音乐、绘画的物理 (离散频谱, 弦), 数学 (几何) 属性, 精神与物理的同构性, 特别重要的是: 它还是和弦时空的观察基 础、认识途径。

\section{两种时空观}

人类有两套时空表达方式: 参考系时空与和弦时空，简单说：参考系时空来自时钟，尺 子等外部度量参考系, 和弦时空来自量子化的离散频谱, 弦 (开弦, 闭弦, 非线弦), 通常, 科学、物理学采用参考系时空方式, 音乐、绘画采用和弦时空方式。

和弦时空是和弦语言的语义表达, 音乐表达时间, 绘画表达空间, 两者都具有离散频谱 形式: 和弦, 调式, 音阶等, 数学上互为反序镜像, 可通过和弦取值公式相互转换。

和弦绘画（和弦几何）中，特定和弦具有特定空间-几何语义: 开弦 (小三和弦), 闭弦 (大三和弦), 非线弦 (不协和弦), 这三种和弦可以产生所有空间状态及空间相互作用, 这 是和弦空间（几何）的基本特征，很容易在和弦绘画中观察、验证，这对弦-M 理论应该是 一个好消息。

再说一遍: 科学、物理学使用参考系时空, 音乐、绘画等使用和弦时空, 下面分别补充 介绍:

参考系时空: 由外部度量参考系: 尺子, 时钟, 背景参考系等产生位置, 形状, 运动描 述, 时空是来自外部参考系的度量值。

和弦时空: 是能量、信息形式: 量子化的和弦频谱、弦 (开弦, 闭弦, $N$ 弦), 并由此 产生时空状态、相互作用及运动, 不依赖时钟, 尺子等外部度量参考系。根据以上特征, 和 弦时空似乎也可称为: 量子-弦时空。

参考系时空会屏蔽和弦时空（量子时空），举一个例子：

用时钟，尺子等外部度量参考系测量和弦时空系统; 如: 贝多芬、莫扎特，梵高、莫奈 的作品, 从测量数值可建立一个时空理论模型, 但基于外部参考系的时空模型中没有和弦频 谱及其能量、信息作用。

时空表达是物理学与音乐-绘画的交叉领域, 也是共同的中心，但它们是不同的时空表 达方式, 甚至是不同的时空观。特别是: 和弦时空具有鲜明的物理形式: 离散频谱, 弦 (开 弦, 闭弦, 非线弦), 这应是量子论, 弦理论特征, 也是本文必须追问的问题。 


\section{其它 Other}

和弦语言是常见人类认识盲区, 有两个原因:

1、两种语言的原理、方法差异：和弦语言通常发生在符号语言的后台、底层, 不依赖 符号语言系统, 不易被符号语言、理性所觉察, 注意。

2、和弦语言的观察基础是: 音乐, 绘画, 经络学等和弦语言现象, 由于教育的原因, 很多人对这一领域不熟悉。

新增知识点: 和弦语言, 和弦时空, 和弦绘画, 和弦数学, 和弦生命。

涉及已有知识点: 音乐理论, 音乐数学, 色彩理论、物理, 生命, 经络学, 万物理论。

\section{Reference}

14. Chord space-time, Li xiaohong,24th World Congress of Philosophy Beijing 13-20 August 2018

15. Spiritual chords, Li xiaohong,24th World Congress of Philosophy Beijing 13-20 August 2018

16. Chord language-Equal temperament logic and Equal temperament painting, Li xiaohong,ISBN:9781370273348

17. Chord language - chord painting atlas, Li xiaohong,ISBN: 9781370273348

18. Greene,Brian.The Elegant Universe, W.W.Norton and Co.New York,NY.c1999 ISBN 0-37570811-1.

19. 加来道雄. 《超越时空》. 上海世纪出版集团. 2009. ISBN 978-7-5428-4804-8.

20. Davis Henry. The Republic The Statesman of Plato: London: M. W. Dunne ， 2010: ISBN 978-1-146-97972-6

21. Dahlhaus, Carl. Gjerdingen, Robert O. trans. (1990). Studies in the Origin of Harmonic Tonality, p. 141. Princeton University Press. ISBN 0-691-09135-8.

22. van der Merwe, Peter (1989). Origins of the Popular Style: The Antecedents of TwentiethCentury Popular Music. Oxford: Clarendon Press. ISBN 0-19-316121-4.

23. Nettles, Barrie \& Graf, Richard (1997). The Chord Scale Theory and Jazz Harmony. Advance Music, ISBN 3-89221-056-X

24. M. Planck, A Survey of Physical Theory, transl. by R. Jones and D.H. Williams, Methuen \& Co., Ltd., London 1925(Dover editions 1960 and 1993)including the Nobel lecture.

25. J. Mehra and H. Rechenberg, The Historical Development of Quantum Theory, Vol.1, Part 1, Springer-Verlag New York Inc., New York 1982.

26. Lucretius, "On the Nature of the Universe", transl. from the Latin by R.E. Latham, Penguin Books Ltd., Harmondsworth 1951. There are, of course, many translations, and the translation's title varies. Some put emphasis on how things work, others on what things are found in nature. 